\title{
BIOAKTIVITAS EKSTRAK Turbinaria decurrens SEBAGAI ANTITUMOR (HeLa DAN T47D) SERTA EFEKNYA TERHADAP PROLIFERASI LIMFOSIT
}

\author{
Nurrahmi Dewi Fajarningsih*), Muhammad Nursid*), Thamrin Wikanta*), \\ dan Endar Marraskuranto*)
}

\begin{abstract}
ABSTRAK
Riset mengenai bioaktivitas ekstrak makroalga Turbinaria decurrens terhadap proliferasi sel limfosit dan sitotoksisitas terhadap sel lestari tumor HeLa dan T47D telah dilakukan. Uji toksisitas dilakukan dengan metode Brine Shrimp Lethality Test (BSLT), sedangkan uji sitotoksisitas terhadap sel tumor HeLa dan T47D dilakukan dengan metode 3-(4,5-dimethylthiazol-2yl)-2,5diphenyltetrazolium bromide]) assay (metode MTT), uji proliferasi limfosit juga dilakukan dengan metode MTT. Hasil uji BSLT menunjukkan bahwa fraksi n-heksana $T$. decurrens memiliki toksisitas tertinggi dengan $\mathrm{LC}_{50}$ sebesar $672,59 \mathrm{ppm}$ sehingga tergolong toksik. Sementara itu, ekstrak T. decurrens mempunyai aktivitas sitotoksisitas terhadap sel tumor HeLa $\left(\mathrm{LC}_{50}\right.$ ekstrak kasar = 29,9 ppm), namun tidak efektif terhadap sel T47D ( LC $_{50}$ ekstrak kasar $>1.000$ ppm). Fraksi n-heksana $T$. decurrens merupakan fraksi yang menunjukkan aktivitas sitotoksisitas terbaik terhadap sel tumor HeLa dengan $\mathrm{LC}_{50}$ sebesar 15,1 ppm. Ekstrak kasar, fraksi metanol, fraksi etil asetat, dan fraksi n-heksana dari makroalga $T$. decurrens mampu meningkatkan proliferasi sel limfosit manusia. Metabolit sekunder dari fraksi n-heksana T. decurrens sangat prospektif dikembangkan sebagai senyawa antitumor.
\end{abstract}

ABSTRACT: Bioactivity of Turbinaria decurrens extract as an antitumor (HeLa and T47D) and its effects on lymphocyte proliferation. By: Nurrahmi Dewi Fajarningsih, Muhammad Nursid, Thamrin Wikanta, and Endar Marraskuranto

Studies to determine the bioactivity of macroalga Turbinaria decurrens extract againts HeLa and T47D tumors and its effect on human lymphocite proliferation have been carried out. Toxicity assay was conducted using Brine Shrimp Lethality Test (BSLT) method while cytotoxicity assay against HeLa, T47D cell lines and for lymphocite proliferation were carried out using 3-(4,5-dimethylthiazol-2yl)-2,5-diphenyltetrazolium bromide]) assay (MTT method). The results of BSLT test showed that $\boldsymbol{T}$. decurrens $n$-hexane fraction has the highest toxicity with Lethal Concentration $_{50}\left(L C_{50}\right)$ value of $672.59 \mathrm{ppm}$. T. decurrens crude ethanol extract showed a high antitumor activity against $\mathrm{HeLa}$ cell lines with $L C_{50}$ value of $29.9 \mathrm{ppm}$. On other hand, the extract showed low bioactivity against $T 47 D$ cell lines $\left(L C_{50}\right.$ value $\left.>1,000 \mathrm{ppm}\right)$. $N$-hexane fraction of $T$. decurrens showed the best bioactivity against $H$ eLa cell lines with $L C_{50}$ value of $15.1 \mathrm{ppm}$, whereas crude ethanol extract, methanol fraction, ethyl acetate fraction, and $n$-hexane fraction of T. decurrens increased the human lymphocyte proliferation. There were evidences that secondary metabolites of $\boldsymbol{T}$. decurrens $n$-hexane fraction had a good potential for the development of nutraceutical products.

KEYWORDS: Turbinaria decurrens, lymphocyte, HeLa, T47D, BSLT, MTT assay

\section{PENDAHULUAN}

Penyakit kanker merupakan salah satu masalah kesehatan yang penting di dunia. Angka kejadian dan kematian akibat kanker terus meningkat setiap tahunnya. Badan Kesehatan Dunia melaporkan bahwa saat ini diperkirakan terdapat 11-12 juta penderita kanker di seluruh dunia dengan 6-7 juta di antaranya berada di negara berkembang. Setiap tahunnya terdapat 190-200 ribu penderita kanker baru di Indonesia (Anon., 2008). Dua jenis kanker dengan angka kejadian terbesar di Indonesia adalah kanker mulut rahim (serviks) dan kanker payudara. Setiap tahunnya sekitar 8.000 wanita Indonesia meninggal dunia akibat kanker mulut rahim (Anon., 2007).

Besarnya angka kematian tersebut disebabkan karena sebagian besar penderita kanker terlambat mendapat pengobatan atau penanganan medis karena berbagai alasan. Selain itu, banyak obat kanker yang ada saat ini memiliki indikasi therapeutic yang rendah, dan dosis maksimum obat yang diberikan hanya memberikan efektivitas yang minimum. Tidak semua pasien dan atau jenis kanker responsif terhadap obatobat kanker yang ada. Bahkan, banyak obat kanker

\footnotetext{
*) Peneliti pada Balai Besar Riset Pengolahan Produk dan Bioteknologi Kelautan dan Perikanan, DKP
} 
yang menimbulkan efek samping dan efek resisten terhadap pasien (William \& Andersen, 2006). Untuk menjawab permasalahan tersebut, riset untuk mendapatkan kandidat potensial obat antitumor baru sangat diperlukan.

Senyawa bahan alam dari makroalga telah terbukti menjadi salah satu sumber senyawa bioaktif baru (Boisson-Vidal et al., 1995; Deslandes, 2000), di antaranya sebagai antimikroba, antivirus, dan antitumor (Satari, 1996). Deslandes et al. (2000) melaporkan adanya efek antiproliferatif ekstrak hidroetanol makroalga Turbinaria oenata terhadap sel lestari NSCLC-N6. Sheu et al. (1999) berhasil mengisolasi beberapa fucosterol baru dari makroalga Turbinaria conoides dengan aktivitas sitotoksik. Makroalga Turbinaria decurrens sangat melimpah di perairan Indonesia. Potensi bioaktivitas T. decurrens sangat menarik untuk diteliti bioaktivitasnya sebagai antitumor.

Model ideal dalam pencarian obat antitumor potensial adalah senyawa bioaktif yang dapat membunuh sel tumor namun memiliki toksisitas rendah terhadap sel normal. Tiga tahapan awal yang harus dilewati untuk pengembangan produk nutrasetikal, meliputi : tahap ekstraksi, tahap skrining biologis, dan uji farmakologi serta tahap uji toksikologi dan keamanan pakai (Sumaryono, 2004).

Penelitian ini bertujuan untuk mempelajari potensi bioaktivitas ekstrak makroalga Turbinaria decurrens sebagai antitumor HeLa (tumor serviks) dan T47D (tumor payudara) serta uji toksikologi secara in vitro terhadap sel limfosit yang diisolasi dari sel darah manusia.

\section{BAHAN DAN METODE}

\section{Pengambilan Sampel, Ekstraksi, dan Fraksinasi}

Makroalga Turbinaria decurrens diambil dari zona pasang surut pantai Binuangeun, Banten. Sampel
T. decurrens segar yang diperoleh sebanyak $10 \mathrm{~kg}$. Sampel dicuci menggunakan air tawar untuk menghilangkan kotoran dan epifit yang menempel, kemudian dimaserasi dalam $10 \mathrm{~L}$ pelarut etanol $95 \%$ selama 3 hari. Larutan yang diperoleh disaring dengan kertas saring Whatman No.41 dan dievaporasi dengan Buchi Rotavapor. Setelah pelarut etanol menguap semua, ekstrak dikeringbekukan (freeze dried) pada suhu $-43^{\circ} \mathrm{C}$ tekanan $280 \times 10^{-3}$ mbar hingga diperoleh ekstrak berbentuk serbuk kering (ekstrak kasar etanol). Setelah dilakukan uji bioaktivitas, selanjutnya ekstrak kasar etanol tersebut difraksinasi secara padat-cair. Proses fraksinasi dilakukan berturut-turut berdasarkan peningkatan kepolaran pelarut dengan menggunakan pelarut n-heksana, etil asetat, dan metanol.

\section{Kultur Sel HeLa dan T47D}

Sel tumor HeLa yang digunakan pada penelitian ini berasal dari US NAMRU (United States Naval Medical Research Unit) Jakarta, sedangkan sel T47D berasal dari koleksi Fakultas Kedokteran UGM, Yogyakarta. Kedua jenis sel seperti terlihat pada Gambar 1, telah dikultur di laboratorium bioteknologi Balai Besar Riset Pengolahan Produk dan Bioteknologi Kelautan dan Perikanan.

Sel HeLa ditumbuhkan dalam medium RPMI 1640 (Sigma) lengkap yang mengandung fetal bovine serum (FBS) 10\% (Gibco), fungizon 0,5\% (Gibco), dan penisilin-streptomisin 2\% (Gibco). Sel T47D ditumbuhkan dalam medium DMEM (Gibco) lengkap yang mengandung FBS 10\% (Gibco) dan penisilinstreptomicin $2 \%$. Kedua sel dikultur menggunakan flask $25 \mathrm{~mL}$ (Nunc) dalam inkubator $\mathrm{CO}_{2}$ pada suhu $37^{\circ} \mathrm{C}$ dan aliran $\mathrm{CO}_{2} 5 \%$.

\section{Isolasi Sel Limfosit}

Isolasi sel limfosit dilakukan menurut metode yang digunakan oleh Wahyuni (2006). Darah dari seorang responden sehat diambil secara steril dan ditambah

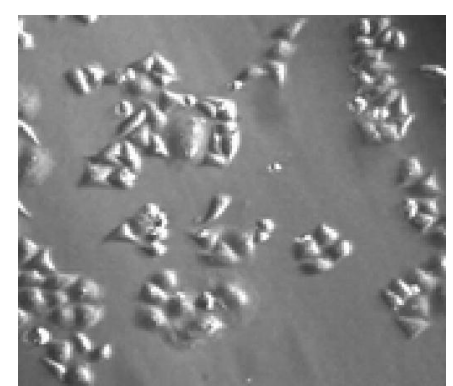

a

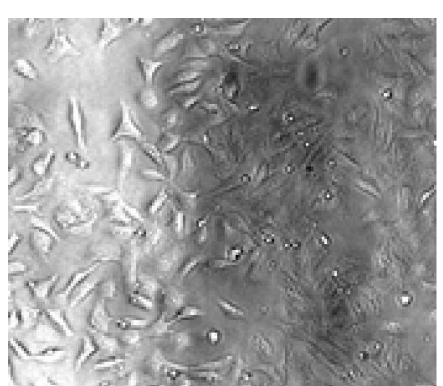

b

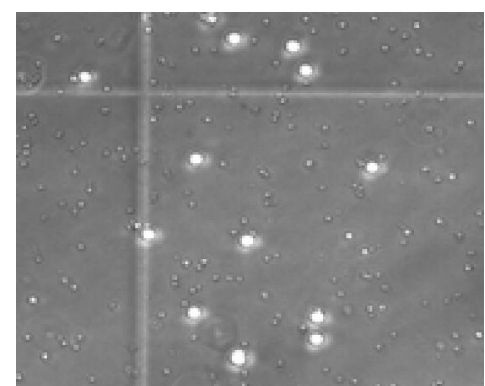

C

Gambar 1. Morfologi sel (a) HeLa, (b) T47D, dan (c) limfosit manusia (perbesaran 100x).

Figure 1. The morphology of cells (a) HeLa, (b) T47D, and (c) human lymphocyte (100x magnification). 
antikoagulan. Pemisahan komponen seluler dilakukan dengan sentrifugasi sampel darah dalam vacutteiner dengan kecepatan 1.000 rpm selama 10 menit. Bagian darah yang berat (sel darah merah) berada di bawah dan plasma darah terpisah di bagian atas. Lapisan buffy coat (berisi sel limfosit) yang terletak di antara kedua lapisan diambil kemudian ditambah dengan medium RPMI. Selanjutnya, suspensi limfosit tersebut dilewatkan pada larutan ficoll-hypaque secara perlahan hingga terbentuk dua lapisan yang terpisah. Kemudian, tabung disentrifugasi lagi dengan kecepatan $1.500 \mathrm{rpm}$ selama 30 menit. Sel limfosit, monosit, dan platelet berada di lapisan atas permukaan ficoll dan tidak menembus ke bawah, sedangkan granulosit dan sel darah merah terpisah di dasar tabung sentrifugasi. Lapisan yang berisi limfosit, monosit, dan platelet dicuci dengan medium RPMI dan disentrifugasi dengan kecepatan 1.500 rpm selama 10 menit. Supernatan dibuang kemudian pelet dicuci dan disentrifugasi kembali dengan kecepatan $1.500 \mathrm{rpm}$ selama 10 menit sehingga limfosit terpisah dari platelet, monosit, dan ficoll (dalam supernatan). Pelet sel yang diperoleh kemudian ditambah medium pertumbuhan RPMI lengkap yang mengandung Fetal Bovine Serum (FBS) $10 \%$, fungizone $0,5 \%$, dan Penisilin-Streptomisin $2 \%$ dan dihomogenkan, kemudian dilakukan penghitungan jumlah sel dengan menggunakan hemositometer.

\section{Pengujian Ekstrak T. decurrens}

\section{Uji toksisitas dengan Brine Shrimp Lethality Test (BSLT)}

Uji toksisitas dilakukan dengan menggunakan metode Brine Shrimp Lethality Test (BSLT) menurut Meyer et al. (1982). Pada uji ini digunakan larva Artemia salina sebagai hewan uji. Telur $A$. salina (merk ARTEMIA) ditetaskan dalam larutan garam fisiologis (38 g garam dapur dalam $1.000 \mathrm{~mL}$ air suling) di bawah lampu TL 15 watt. Setelah 48 jam, telur menetas menjadi nauplii instar III/IV, siap digunakan sebagai hewan uji.

Larutan stok ekstrak dibuat dengan konsentrasi 10.000 ppm. Ekstrak kasar etanol, fraksi n-heksana, fraksi etil asetat, dan fraksi metanol makrolaga $T$. decurrens dilarutkan dalam dimetil sulfoksida (DMSO) sebagai larutan stok. Selanjutnya, dibuat seri konsentrasi ekstrak sebesar 6,$25 ; 12,5 ; 25 ; 50$; dan 100 ppm dari larutan stok tersebut. Pengenceran dilakukan dengan menggunakan larutan garam fisiologis. Sebagai kontrol, digunakan larutan garam dan 1\% DMSO (konsentrasi DMSO tertinggi pada perlakuan). Maksimal kematian larva $A$. salina pada kontrol tidak boleh melebihi $10 \%$ dari total populasi uji.
Sepuluh ekor larva $A$. salina dimasukkan ke dalam vial yang berisi ekstrak sampel dalam berbagai seri konsentrasi. Masing-masing perlakuan dan kontrol dilakukan tiga kali ulangan. Selanjutnya, semua vial diinkubasikan di bawah lampu TL 15 watt selama 24 jam. Setelah diinkubasi, jumlah larva $A$. salina yang mati pada tiap vial dihitung untuk menentukan persentase kematiannya. Nilai Lethal Concentration ${ }_{50}$ $\left(\mathrm{LC}_{50}\right)$ dihitung dengan menggunakan analisis probit dengan program MINITAB versi 13.2 dengan selang kepercayaan $95 \%$.

\section{Uji sitotoksisitas terhadap sel kanker HeLa dan T47D}

Uji sitotoksisitas dilakukan dengan metode MTT (3-[4,5-dimetilthiazol-2yl]-2, 5-difenil tetrazolium bromida) menurut Zachary (2003). Dibuat seri konsentrasi ekstrak $T$. decurrens sebesar 12,5; 25; 50; 100; dan 200 ppm dengan menggunakan pelarut medium pertumbuhan sebanyak 3 ulangan. Dibuat pula 3 macam kontrol, yaitu : kontrol sel tumor (100 $\mu \mathrm{L}$ sel tumor $+100 \mu \mathrm{L}$ media), kontrol media $(200 \mu \mathrm{L}$ media), dan kontrol sampel ( $100 \mu \mathrm{L}$ ekstrak T. decurrens $+100 \mu \mathrm{L}$ media). Sebanyak $100 \mu \mathrm{L}$ larutan ekstrak $T$. decurrens dari setiap konsentrasi dimasukkan ke dalam sumuran mikroplat yang telah berisi sel tumor sebanyak $2 \times 10^{4}$ sel $(100 \mu \mathrm{L})$. Mikroplat kemudian diinkubasikan selama 24 jam dalam inkubator $\mathrm{CO}_{2}$, selanjutnya ditambahkan $10 \mu \mathrm{L}$ MTT ke dalam tiap sumuran mikroplat dan diinkubasikan kembali selama 4 jam dalam inkubator $\mathrm{CO}_{2}$. Reaksi MTT dihentikan dengan penambahan sodium dodesil sulfat (SDS) $10 \%$, selanjutnya mikroplat kembali diinkubasikan selama 12 jam dalam ruang gelap pada suhu kamar. Setelah inkubasi tersebut, absorbansi tiap sumuran diukur dengan spectrophotometer microplate reader (DYNEX technologies tipe $M R X)$ pada panjang gelombang 570 $\mathrm{nm}$.

Penentuan persentase kematian sel dihitung berdasarkan rumus:

$$
\begin{aligned}
\text { Mortalitas }=\frac{(A-D) \quad(B-C)}{(A-D)} \times 100 \% \\
\text { Keterangan: } \quad \begin{aligned}
A & =\text { Absorbansi kontrol sel } \\
B & =\text { Absorbansi sampel } \\
C & =\text { Absorbansi kontrol sampel } \\
D & =\text { Absorbansi kontrol media }
\end{aligned}
\end{aligned}
$$

Perhitungan nilai Lethal Concentration ${ }_{50}\left(\mathrm{LC}_{50}\right)$ dilakukan dengan menggunakan analisis probit dengan program MINITAB versi 13.2 dengan selang kepercayaan $95 \%$. 


\section{Uji proliferasi limfosit}

Uji proliferasi limfosit juga dilakukan dengan metode MTT (3-[4,5-dimetilthiazol-2yl]-2,5-difenil tetrazolium bromida) menurut Zachary (2003). Namun, jumlah sel limfosit yang digunakan adalah sebanyak $2 \times 10^{5}$ sel dalam tiap sumuran.

Penentuan persentasi proliferasi limfosit dilakukan menggunakan rumus:

Proliferasi limfosit $=\frac{\text { absorbansi sampel }}{\text { absorbansi kontrol }} \times 100 \%$

\section{HASIL DAN BAHASAN}

\section{Uji Toksisitas}

Tingkat toksisitas suatu ekstrak dapat diketahui dengan menghitung persentase kematian naupli artemia sebagai hewan uji dalam BSLT. Hasil perhitungan $\mathrm{LC}_{50}$ uji BSLT ekstrak $T$. decurrens dari penelitian ini ditampilkan dalam Tabel 1.

Suatu ekstrak dianggap sangat toksik bila memiliki nilai $\mathrm{LC}_{50}$ di bawah $30 \mathrm{ppm}$, dianggap toksik bila memiliki nilai $L_{50} 30-1.000$ ppm dan dianggap tidak toksik bila nilai $L_{50}$ di atas 1.000 ppm
(Meyer et al., 1982). Berdasarkan Tabel 1, dapat diketahui bahwa ekstrak $T$. decurrens fraksi n-heksana dengan $\mathrm{LC}_{50}$ sebesar $672,59 \mathrm{ppm}$ termasuk dalam kategori toksik. Sementara ekstrak T. decurrens yang lain cenderung bersifat tidak toksik terhadap larva artemia.

Carballo et al. (2002) meneliti kelayakan penggunaan metode BSLT untuk pengujian aktivitas farmakologi produk bahan alam dari laut. Hasil penelitian tersebut menunjukkan adanya korelasi positif antara BSLT dan uji sitotoksik terhadap sel tumor paru-paru A-549 dan sel tumor kolon HT-29, dimana $50 \%$ spesies yang aktif dalam BSLT juga aktif dalam uji sitotoksik. Sementara itu, penelitian Fajarningsih et al. (2006) menunjukkan bahwa BSLT dapat mengeliminasi $53,9 \%$ sampel spons dan soft coral yang tidak aktif dalam uji sitotoksik terhadap sel tumor HeLa.

\section{Aktivitas Sitotoksik Terhadap Sel Lestari Tumor HeLa dan T47D}

Uji sitotoksik digunakan sebagai skrining tahap awal untuk mengetahui pengaruh suatu bahan dalam menghambat pertumbuhan sel tumor. Hasil perhitungan $\mathrm{LC}_{50}$ ekstrak $T$. decurrens disajikan pada Tabel 2.

Tabel 1. Nilai LC $_{50}$ (ppm) uji BSLT ekstrak kasar etanol, fraksi metanol, fraksi etil asetat, dan faksi n-heksana T. decurrens

Table 1. BSLT LC ${ }_{50}$ value (ppm) of T. decurrens's crude ethanol extract, methanol, ethyl acetate, and $n$-hexane fractions

\begin{tabular}{lc}
\hline \multicolumn{1}{c}{ Sampel/Sample } & $\mathbf{L C}_{50}$ \\
\hline Ekstrak kasar etanol/Crude ethanol extract & $>1,000$ \\
Fraksi methanol/Methanol fraction & $>1,000$ \\
Fraksi etil asetat/E thyl acetate fraction & $>1,000$ \\
Fraksi n-heksana/N-hexane fraction & 672.59 \\
\hline
\end{tabular}

Tabel 2. Nilai $\mathrm{LC}_{50}(\mathrm{ppm})$ ekstrak kasar etanol, fraksi metanol, fraksi etil asetat, dan faksi n-heksana T. decurrens terhadap sel HeLa dan sel T47D

Table 2. $L C_{50}$ value (ppm) of T. decurrens's crude ethanol extract, methanol, ethyl acetate, and n-hexane fractions against HeLa and T47D cell lines

\begin{tabular}{lcc}
\hline \multicolumn{1}{c}{ Sampel/Sample } & HeLa & T47D \\
\hline Ekstrak kasar etanol/Crude ethanol extract & 29.90 & $>1,000$ \\
Fraksi methanol/Methanol fraction & 24.50 & 574.30 \\
Fraksi etil asetat/E thyl acetate fraction & 47.31 & 144.90 \\
Fraksi n-heksana/N-hexane fraction & 15.10 & $>1,000$ \\
\hline
\end{tabular}


Menurut Andersen (1991) dalam Sismindari et al. (2002), suatu ekstrak kasar dianggap aktif apabila mampu menghambat pertumbuhan $50 \%$ populasi sel tumor pada konsentrasi di bawah $30 \mathrm{ppm}\left(\mathrm{LC}_{50}<30\right.$ ppm). Hasil pada penelitian ini, seperti terlihat pada Tabel 2. di atas, menunjukkan bahwa ekstrak kasar T. decurrens memiliki aktivitas sitotoksik terhadap sel HeLa dengan $\mathrm{LC}_{50}$ sebesar 29,9 ppm, namun tidak memiliki aktivitas sitotoksik terhadap sel T47D dengan $\mathrm{LC}_{50}$ ekstrak kasar $>1.000$ ppm. Fraksi n-heksana $T$. decurrens mempunyai aktivitas sitotoksik terbaik terhadap sel tumor HeLa dengan $\mathrm{LC}_{50}$ sebesar 15,1 ppm. Berdasarkan hal tersebut, maka dapat diperkirakan bahwa senyawa-senyawa aktif antitumor HeLa T. decurrens terdapat pada fraksi ini.

Sel tumor merupakan sel normal yang kemudian mengalami perubahan genetis (mutasi) hingga pertumbuhannya menjadi tidak normal. Setiap sel memiliki respon fisiologis yang berbeda terhadap rangsang yang diberikan dari luar, dalam hal ini adalah pemberian senyawa bioaktif ekstrak $T$. decurrens. Siklus sel merupakan peristiwa yang sangat kompleks, yang melibatkan sekuens spesifik yang berperan dalam mengatur pertumbuhan dan proliferasi sel. Secara umum, siklus sel akan menjadi tidak terkendali pada sel kanker (Buolamwini, 2000). Sejumlah senyawa bioaktif dapat menghambat proliferasi sel kanker melalui jalur metabolisme sel yang teregulasi. Setiap senyawa bioaktif dapat bekerja melalui berbagai mekanisme yang berbeda (Deslandes et al., 2000).

Sumber daya hayati laut merupakan "reservoir" metabolit sekunder unik dengan berbagai potensi bioaktivitas, di antaranya berpotensi sebagai antitumor. Kahalalide $F$ yang diisolasi dari alga Bryopsis sp. memiliki aktivitas sebagai antitumor paru-paru, kolon dan prostat. Senyawa aktif tersebut bahkan telah dipatenkan sebagai kandidat substansi aktif dalam pengobatan kanker paru-paru (Smit, 2004). Ada dua model yang dikembangkan dalam riset pencarian senyawa bioaktif antitumor dari bahan alam.
Model pertama adalah mencari bahan alam yang memiliki toksisitas yang tinggi (sangat toksik terhadap berbagai jenis sel). Sedangkan model yang lain adalah mencari senyawa bioaktif yang dapat membunuh sel tumor secara spesifik.

Pada Tabel 2 dapat diketahui bahwa fraksi $n$ heksana $T$. decurrens merupakan fraksi dengan bioaktivitas antitumor HeLa yang terbaik, dimana nilai $\mathrm{LC}_{50}$ fraksi n-heksana adalah sebesar $15,1 \mathrm{ppm}$ (tergolong sangat aktif). Secara ilmiah, dapat diduga senyawa-senyawa aktif $T$. decurrens dengan potensi bioaktivitas antitumor berada pada fraksi ini.

Sheu et al. (1999), mempublikasikan 9 senyawa fucosterol yang diisolasi dari alga coklat $T$. conoides. Empat senyawa di antaranya memiliki bioaktivitas terhadap beberapa sel lestari tumor. Senyawa tersebut adalah, 24-ethylcholesta-4,24(28)-dien-3,6-dione, 24hydroperoxy-24-ethylcholesta-4,28(29)-dien-3,6-dione dan 6ß-hydroxy-24-ethylcholesta-4,24(28)-dien-3-one yang secara signifikan memiliki efek sitotoksik terhadap sel lestari tumor P-388, A-549 dan HT-29. Senyawa 24-hidroperoxy-6ß-hydroxy-24-ethylcholesta4,-28(29)-dien-3-one bahkan menunjukkan efek sitotoksik yang kuat terhadap sel lestari tumor P-388, A-549, HT-29 dan KB dengan $\mathrm{ED}_{50}$ berkisar antara $(0,4-1,8 \mathrm{ppm})$.

\section{Uji Proliferasi Limfosit}

Bioaktivitas ekstrak $T$. decurrens terhadap proliferasi limfosit disajikan pada Tabel 3. Tampak bahwa ekstrak $T$. decurrens tidak bersifat toksik terhadap sel limfosit, bahkan dapat memacu terjadinya proliferasi limfosit.

Uji proliferasi limfosit dilakukan untuk mengetahui bioaktivitas ekstrak makroalga T. decurrens terhadap sel limfosit yang diberlakukan sebagai sel normal manusia. Apabila ekstrak tersebut tidak bersifat toksik pada sel limfosit, maka dapat dihipotesiskan bahwa ekstrak tersebut juga tidak toksik pada sel normal. Hasil uji proliferasi limfosit ekstrak T. decurrens fraksi

Tabel 3. Proliferasi sel limfosit yang diberi perlakuan 12,5; 25; dan 50 ppm ekstrak kasar etanol, fraksi metanol, fraksi etil asetat, dan faksi n-heksana T. decurrens (\%)

Table 3. Proliferation of lymphocyte cell which is treated with T. decurrens's crude ethanol extract, methanol, ethyl acetate, and $n$-hexane fractions (\%)

\begin{tabular}{llcc}
\hline \multicolumn{1}{c}{ Sampel/Sample } & $\mathbf{5 0} \mathbf{~ p p m}$ & $\mathbf{2 5} \mathbf{~ p p m}$ & $\mathbf{1 2 . 5} \mathbf{~ p p m}$ \\
\hline Ekstrak kasar etanol/Crude ethanol extract & 109.660 & 101.468 & 104.230 \\
Fraksi methanol/Methanol fraction & 149.750 & 141.602 & 193.190 \\
Fraksi etil asetat/E thyl acetate fraction & 126.110 & 113.470 & 99.290 \\
Fraksi n-heksana/N-hexane fraction & 131.726 & 118.137 & 121.480 \\
\hline
\end{tabular}


n-heksana memperlihatkan ekstrak tersebut pada konsentrasi $50 \mathrm{ppm}$ dapat memacu proliferasi limfosit sebesar 1,32 kali dari jumlah sel awal dan pada konsentrasi $25 \mathrm{ppm}$ dapat memacu proliferasi limfosit sebesar 1,18 kali dari jumlah sel awal.

Limfosit adalah sel darah putih (leukosit) yang mampu menghasilkan respon imun spesifik terhadap berbagai jenis antigen yang berbeda (Wahyuni, 2006). Sel limfosit terdiri dari sel limfosit B, sel limfosit T, dan sel Natural Killer (NK cells). Sel limfosit B memproduksi antibodi yang menyerang sel-sel asing (imunitas humoral). Sel limfosit T secara langsung menyerang sel-sel kanker dan memberi sinyal pada sistem imun yang lain untuk mempertahankan tubuh (imunitas seluler), sedangkan sel NK memproduksi zat kimia yang menghancurkan dan membunuh sel asing di dalam tubuh (Siahaan, 2005). Secara in vitro, sel NK dapat membunuh beberapa jenis tertentu sel lestari tumor dan memperlihatkan mekanisme penghancuran sel-sel tertentu sebelum berkembang menjadi tumor. Sel NK akan menginduksi sel yang terinfeksi untuk mati secara alami / apoptosis (Karp, 2005).

Respon proliferatif kultur limfosit dalam media sintetik dapat digunakan untuk menggambarkan fungsi limfosit dan status imun individu. Kemampuan limfosit untuk berproliferasi atau membentuk klon menunjukkan secara tidak langsung kemampuan respon imunologik/tingkat kekebalan (Wahyuni, 2006).

Model ideal pencarian obat antitumor adalah yang bersifat toksik terhadap sel tumor namun aman terhadap sel normal. $T$. decurrens fraksi n-heksana memiliki bioaktivitas yang baik sebagai antitumor HeLa dan bersifat tidak toksik terhadap sel limfosit, bahkan dapat memacu proliferasi limfosit. Metabolit sekunder pada fraksi n-heksana T. decurrens berpotensi untuk dikembangkan sebagai produk nutrasetikal alami dan perlu diteliti lebih lanjut bioaktivitasnya sebagai antitumor.

\section{KESIMPULAN}

Berdasarkan hasil penelitian diketahui bahwa:

1. Ekstrak T. decurrens menunjukkan potensi bioaktivitas sebagai antitumor HeLa, namun kurang berpotensi sebagai antitumor T47D. Fraksi n-heksana $T$. decurrens merupakan fraksi yang menunjukkan aktivitas sitotoksik terbaik terhadap sel tumor HeLa dengan $\mathrm{LC}_{50}$ sebesar $15,1 \mathrm{ppm}$.

2. Ekstrak kasar, fraksi metanol, fraksi etil asetat, dan fraksi n-heksana makroalga $T$. decurrens mampu meningkatkan proliferasi sel limfosit manusia.

3. Metabolit sekunder pada fraksi n-heksana $T$. decurrens berpotensi untuk dikembangkan sebagai produk nutrasetikal alami dan perlu diteliti lebih lanjut bioaktivitasnya sebagai antitumor.

\section{SARAN}

Senyawa aktif dari fraksi n-heksana T. decurrens perlu dipurifikasi lebih lanjut untuk mendapatkan informasi mengenai isolat aktifnya. Selain itu, mekanisme aksi secara molekuler dari senyawa bioaktif $T$. decurrens sebagai antitumor HeLa juga perlu dipelajari.

\section{DAFTAR PUSTAKA}

Anonim. 2007. Kanker mulut rahim renggut 8.000 wanita Indonesia per tahun. www.antara.co.id/arc/2007/9/20/ kanker-mulut-rahim-rengut-8000-wanita-indonesiaper-tahun. Diakses tanggal 28 Maret 2008.

Anonim. 2008. Hanya 15 persen penderita kanker di Indonesia tertangani. www.antara.co.id/arc/2008/1/ 17/hanya-15-persen-penderita-kanker-di-indonesiatertangani. Diakses tanggal 28 Maret 2008.

Boisson-Vidal, C., Haroun, F., Ellouali, M., Blondin, C., and Jozefonvicz, J. 1995. Biological activities of polysaccharides from marine algae. Drugs of The Future. 20: 1237-1249.

Buolamwini, J.K. 2000. Cell cycle molecular targets in novel anticancer drug discovery. Current Pharmaceutical Design. 6: 379-392.

Carballo, J.L., Hernandez-Inda, Z.L., Perez, P., and Garcia-Gravalos, M.D. 2002. A comparison between two brine shrimp assay to detect in vitro cytotoxicity in marine natural product (Methodology Article). BMC Biotechnology 2: 1-5.

Deslandes, E., Pondaven, P., Auperin, T., Roussakis, C.C., Guezennec, J., Stiger, V., and Payri, C. 2000. Preliminary study of the in vitro antiproliferative effect of a hydroethanolic extract from the subtropical seaweed Turbinaria oenata (Turner J. Agardh) on a human non-small-cell bronchopulmonary carcinoma line (NSCLC-N6). J. of Applied Phycology. 12: 257262.

Fajarningsih, N.D., Januar, H.I., Wikanta, T., and Nursid, M. 2006. Correlation between brine shrimp lethality test and cytotoxicity assay in marine natural product screening. Proceeding International seminar and workshop marine biodiversity and their potential for developing bio-pharmaceutical industry in Indonesia. Research Center for Marine and Fisheries Product Processing and Biotechnology, Jakarta. p. 136-141

Karp, G. 2005. Cell and Molecular Biology. John Wiley and Sons Inc., USA. p. 700-703.

Meyer, B.N., Ferrigni, N.R.M., Putman, J.E., Jacobsen, L.B., Nicholas, D.E., and McLauglin, J.L. 1982. Brine shrimp: A convenient general bioassay for active plant constituents. Planta Med. 45: 34-35.

Satari, R. 1996. Potensi pemanfaatan rumput laut. In Atmadja, W.S., Kadi, A., Sulistijo, dan Satari, R. (eds.). 
Pengenalan Jenis-Jenis Rumput Laut Indonesia. Puslitbang Oseanologi, LIPI, Jakarta.

Sheu, J.H., Wang, G.H., Sung, P.J., and Duh, C.Y. 1999. New cytotoxic oxygenated fucosterols from the brown alga Turbinaria conoides. J. of Nat. Prod. 62(2): 224227.

Siahaan, R. 2005. Terapi biologi kanker. www.humanmedicine.net. Diakses tanggal 2 Januari 2007.

Sismindari, A.S., Handayani, Yulia, S., dan Candra, E. 2002. Potent effect of protein extract containing ribosome-inactivating proteins (RIPs) isolated from Erythrina fusca lour on cancer cells. Indonesian $\mathrm{J}$. Biotechnology. p. 559-564.

Smit, A.J. 2004. Medicinal and pharmaceutical uses of seaweed natural products: A review. J. Appl. Phycology. Netherland. 16: 245-262.

Sumaryono, W. 2004. Prospek, Tantangan dan Strategi Pengembangan Bioteknologi Kelautan di
Indonesia. Forum Bioteknologi Kelautan dan Perikanan Indonesia, Jakarta.

Wahyuni, S. 2006. Aktivitas Kitooligomer Hasil Reaksi Enzimatik Terhadap Proliferasi Sel Limfosit dan Sel Kanker. Disertasi. Sekolah Pascasarjana, Institut Pertanian Bogor, Bogor.

Williams, D.E. and Andersen, R.J. 2006. Coral reefs to clinical trials: Bio prospecting for drugs from the sea. Report on International Seminar and Workshop on Marine Biodiversity and Their Potential for Developing Bio-pharmaceutical Industry in Indonesia. Research Center for Marine and Fisheries Product Processing and Biotechnology, Book 2. Jakarta. p. 80-92

Zachary, I. 2003. Determination of cell number. In Hughes, D. and Mehmet, H. (eds.). Cell Proliferation and Apoptosis. BIOS Scientific Publisher Limited. 373 pp. 
